\title{
SENATE BUILDING OF CANADA CASE STUDY: SEISMIC REHABILITATION
}

\author{
LISA M. NICOL ${ }^{1}$ \\ ${ }^{1}$ Senior Structural Engineer \\ at John G. Cooke \& Associates Ltd. (JCAL) \\ 17 Fitzgerald Road, Suite 200 \\ Ottawa, Ontario K2H 9G1 \\ e-mail: lnicol@jgcooke.com, www.jgcooke.com
}

Keywords: Historical Structure, Seismic, Masonry, Rehabilitation

\begin{abstract}
Ottawa's landmark Union Station was constructed between 1902 and 1912 to house Ottawa's central railway station. Located in the Ottawa downtown core, it's situated a short distance from Parliament Hill and across the street from the iconic Fairmont Chateau Laurier Hotel. In the early 1960s, the train tracks and train sheds were removed and replaced with Colonel By Drive parkway. The building sat vacant for quite some time, until it was revived when it underwent renovations in the early 1970s. A south addition was added with a unique geodetic canopy structure. The former Union Station had officially been adapted into the Government Conference Centre, which it remained until this rehabilitation project 2014-2018, which transformed the building into the temporary house of the Senate of Canada. The building was not accessible to the public when it was a Conference Centre, however since 2018 the building is again open to the public for the first time in 55 years.

The client's objective for this rehabilitation was to increase useable floor space. A seismic upgrade of the existing heritage building was also required, along with the design of a new east addition. Existing floor plates required upgrading based on new user requirements. High heritage areas of the building had to be maintained in their original integrity and worked into the design upgrade.

Creative solutions were demanded to bring this existing heritage masonry building up to current seismic code, without the structure taking any more room within the floor spaces. Maximizing space was absolutely critical. As well as, ensuring the new building materials were compatible with the existing heritage building materials. Innovation was found in the balance between a minimal intervention approach and upgrading for current code requirements.
\end{abstract}

\section{INTRODUCTION}

The building was constructed with five distinct Blocks, originally there were only four blocks. In the 1970 upgrades the South Addition was added to the end of the building. 


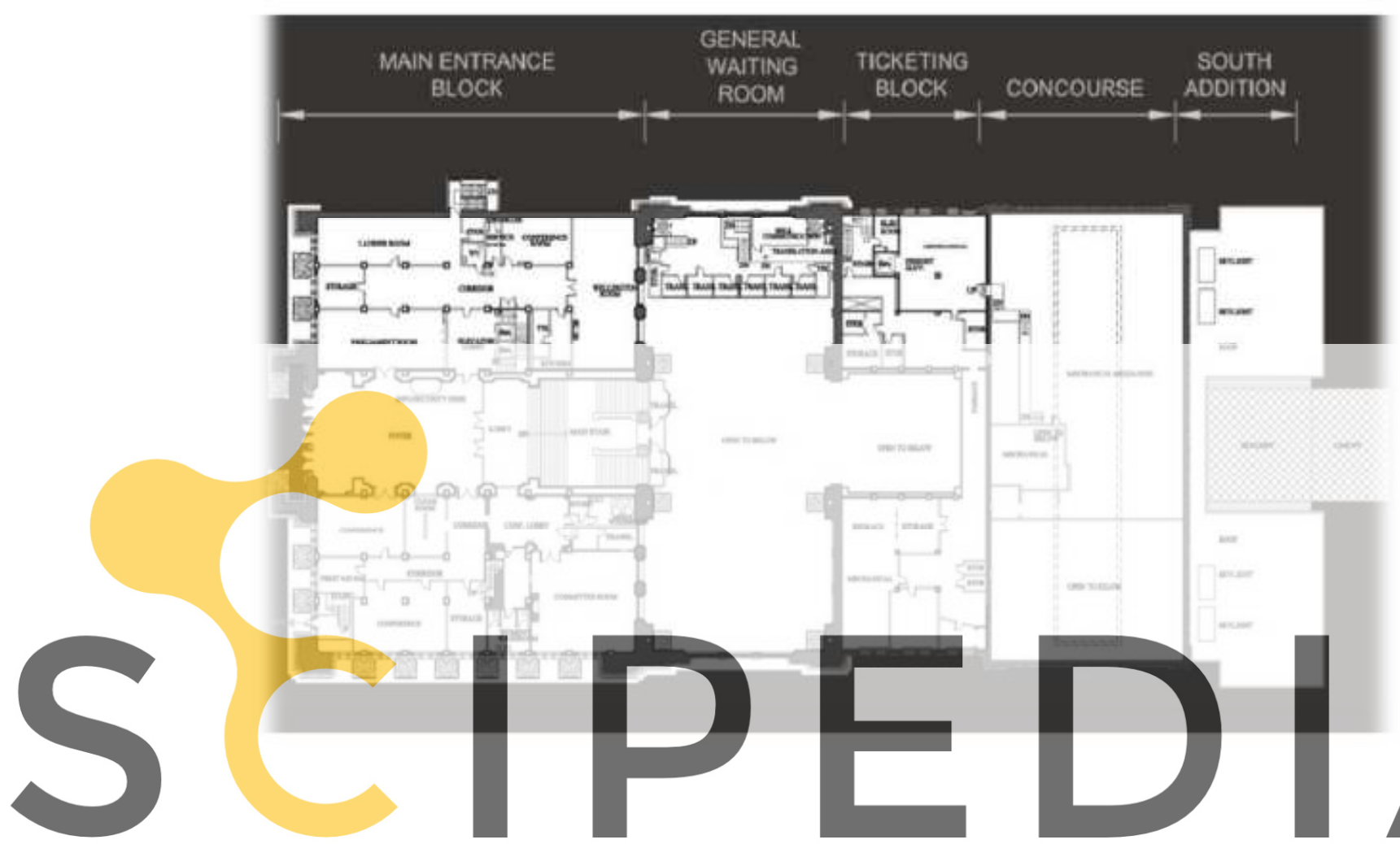

Figure 1: First floor plan (pre-2014)

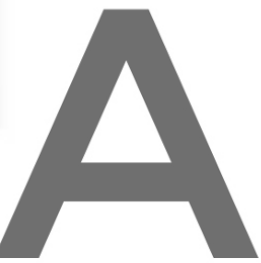

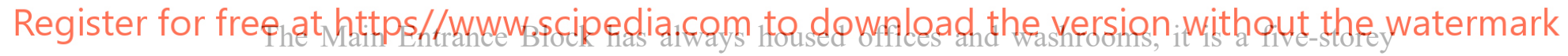
structure.

The General Waiting Room is a four-storey structure and was originally where the public would wait for their trains and say their hellos/goodbyes to people coming or going. This area was a conference room and event space when the building was a Government Conference Centre.

The Ticketing Block is a three-storey structure and it was the block where one could purchase train tickets. As a Conference Centre the block was used as back of house rooms and mechanical/electrical rooms.

The Concourse was the block where the public met their trains, it is a two-storey structure. As a Conference Centre this area was used as event space and had a kitchen area as well as a mechanical mezzanine cutting the height of the area in two. 


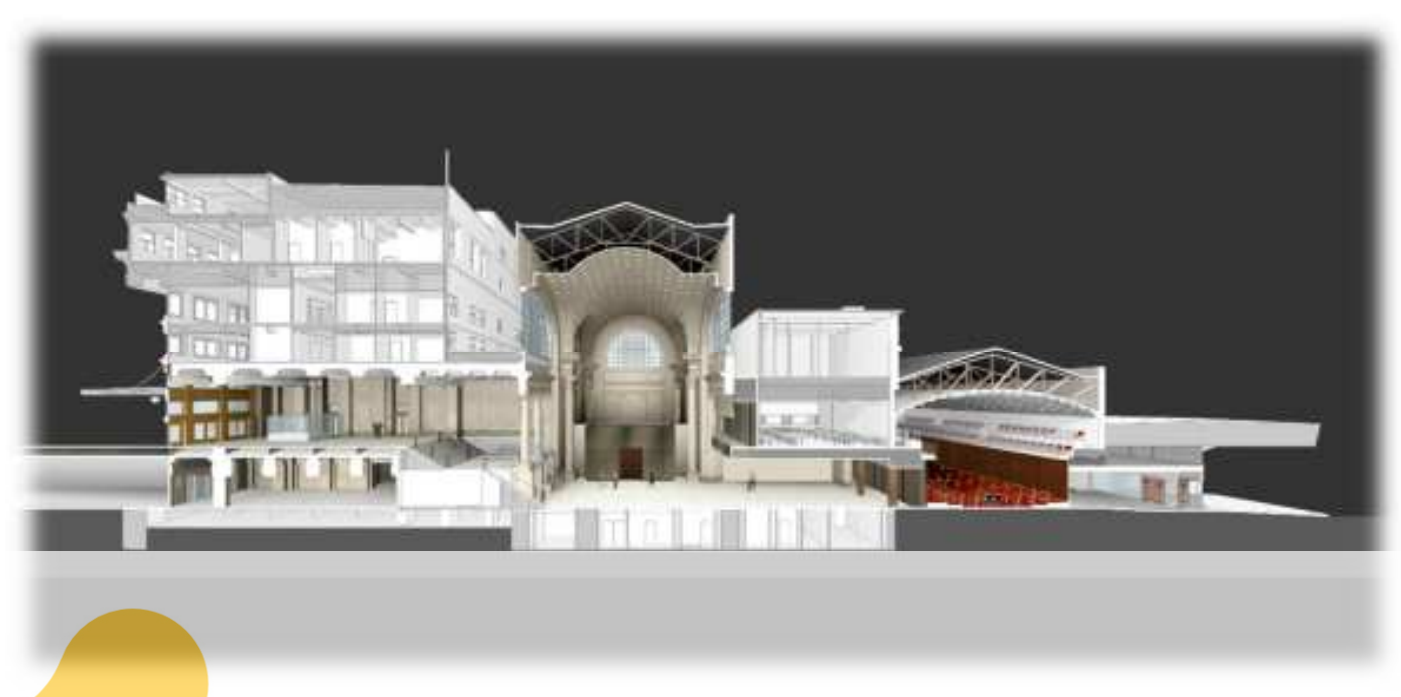

Figure 2: Section through building - New Layout (post-2014)

The building has very distinct blocks structurally as well, as shown from the section through the building. The first few storeys of the building are tied together but above the $2^{\text {nd }}$ floor level

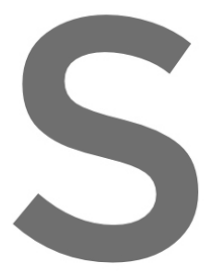
the blocks are essentially independent from each other. Solving the seism because there were s abundance of multi in good condition.
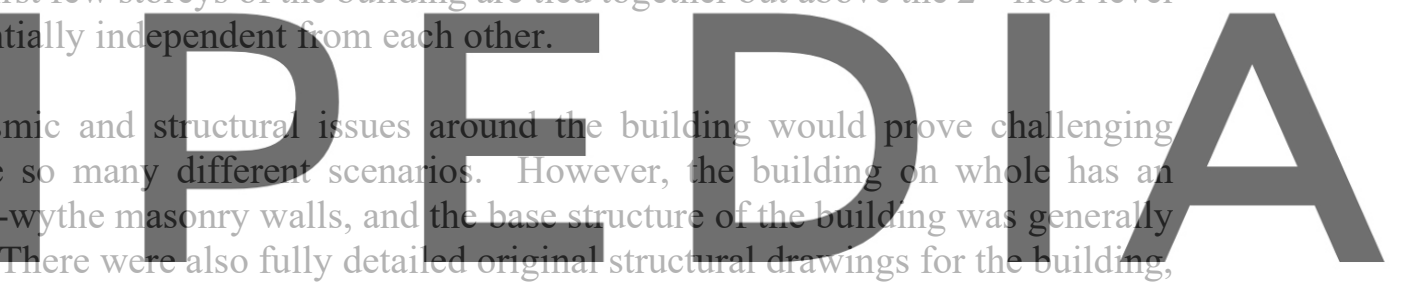

which helped a great deal in anticipating what was found once finishes were removed.

Register for free at https//www.scipedia.com to download the version without the watermark

\section{PROJECT INITIATION AND CONTEXT}

The driving reason for this rehabilitation project was that the Senate of Canada was looking for a temporary home while their original home, East Block on Parliament Hill in Ottawa, was undergoing its own renovations.

Secondary reasons for the rehabilitation were that incongruent upgrades were done in the 1970s, along with piecemeal additions. The bottom line was that the space was not effectively used and access between the building blocks was non-existent except at the ground floor level.

\subsection{Is a seismic upgrade necessary?}

When considering whether a seismic upgrade was necessary, a quick review of the proposed functional program for the Senate made it clear that there were major changes to the occupancy in some areas of the building. This brings the structural capacity into question, as the new loading would be higher/different than the historic floor loading would have been. 
There was a new addition proposed, which added more weight to the building as well as more floor square footage, which would trigger a seismic upgrade of the existing structure unless the new structure was designed as a separate building.

The tipping point was that, seismic upgrade or not, the building would be under construction for several years, so there was a huge opportunity to bring the whole building up to current codes and standards.

\subsection{Structural mandate}

Through initial schematic designs with the Consultant team, the following became the major structural changes to the building:

- Seismic upgrade to a minimum of $60 \%$ National Building Code Canada (NBCC) loads. The project was able to upgrade to $75 \%$ of the NBCC.

- New 5 storey addition along east side of building.

- New first floor level structure with General Waiting Room (GWR) Block, at both the east and west ends of the block. These structures had to be completely independent from the existing building, to ensure the solution was completely reversible, within this high heritage space.

- New first floor level structure within the Concourse Block.

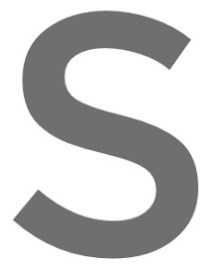

- New full basemen
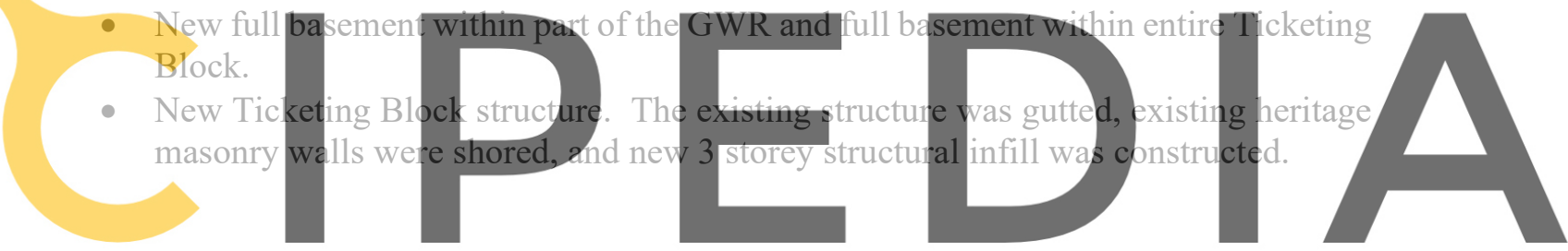

3 EXISTING BUILDING STRUCTURES

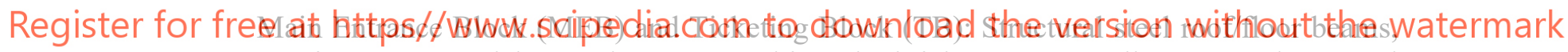
supporting concrete slabs. Columns or multi-wythe brick masonry walls support these steel beams.

General Waiting Room (GWR): Structural steel roof trusses span the full width of this block. The trusses bear on structural steel columns that are embedded into huge multi-wythe brick piers along the north and south walls.

Concourse Block: Structural steel roof trusses span the full width of this block. The trusses bear on structural steel columns that are embedded into the multi-wythe brick wall along the north wall of this block. Along the south wall, the trusses bear on a huge structural steel truss that spans the full length of the block.

South Addition: Structural steel skeleton, with conventional lateral resisting system. It is presumed that the unreinforced concrete block masonry, along with the pre-cast panel façade, acted as the lateral resisting system. 


\subsection{Condition of existing structure}

The condition of the structural steel within the building was excellent, apart from the structural steel framing the ground floor of the Ticketing Block which was rusting to various degrees. This framing was removed when the Ticketing Block structure was demolished.

The brick and stone masonry load bearing walls were generally in good condition. A masonry restoration program was completed over the course of this project to ensure the masonry was in the best condition possible, as all of the walls were used as shearwalls within the new design.

\section{HERITAGE CONSERVATION VS STRUCTURAL/SEISMIC UPGRADES}

Heritage Rehabilitation projects are the most challenging and most innovative because there is constant tension between two opposing objectives 1) creating a design that has minimal impact on the existing structure and 2) meeting current seismic code requirements. The structural designs for heritage buildings are endlessly being assessed based on the question - is this the least intrusive solution?

This requires an understanding of how the existing materials perform and finding compatible

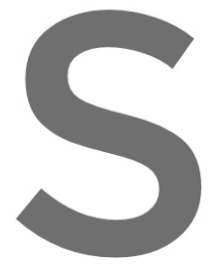

solutions to satisfy the two opposing objectives. When using the existing building nnaterials to the fullest extent of their capacities, the new reinforcing required in the building naturally becomes a minima

Becoming comfortable with heritage materials, and the way testing for physical properties and assessment of the exist

Register for free at https//www.scipedia.com to download the version without the watermark

To gain the seismic upgrade required, the focus was on reinforcing existing building elements, to minimize the space required for new structural elements as well as to minimize the impact of the upgrade on the existing structure.

A few examples of these structural seismic solutions used to achieve the client's main objectives are discussed below.

Excavation/underpinning was undertaken within the basement of the Ticketing Block and GWR, to increase usable floor space. This allowed the East Addition required to be much smaller and therefore have a smaller impact to the heritage façade overall. This also served to minimize the overall seismic forces acting on the existing building because extra floor space was created below grade.

A seismic upgrade of the existing building was complete, integrating the existing stone and brick masonry walls as lateral resisting elements. Using the masonry walls as shearwalls instead of modelling them as simple gravity walls, allowed for cost effective space savings. 
This involved a full masonry restoration program to ensure the masonry walls were in good condition structurally.

A hybrid model was created in ETABS. Existing masonry walls were input as shearwalls with physical properties determined by on site testing. New concrete shearwalls were introduced where new stairwells or elevator shafts were created for the functional program. Concrete shearwalls were ideal for consistency of stiffness of materials. From the model, the most effective locations for new shearwalls could be established, loading on the existing masonry walls could be easily calculated and the existing capacities of existing floor structures was also determined.

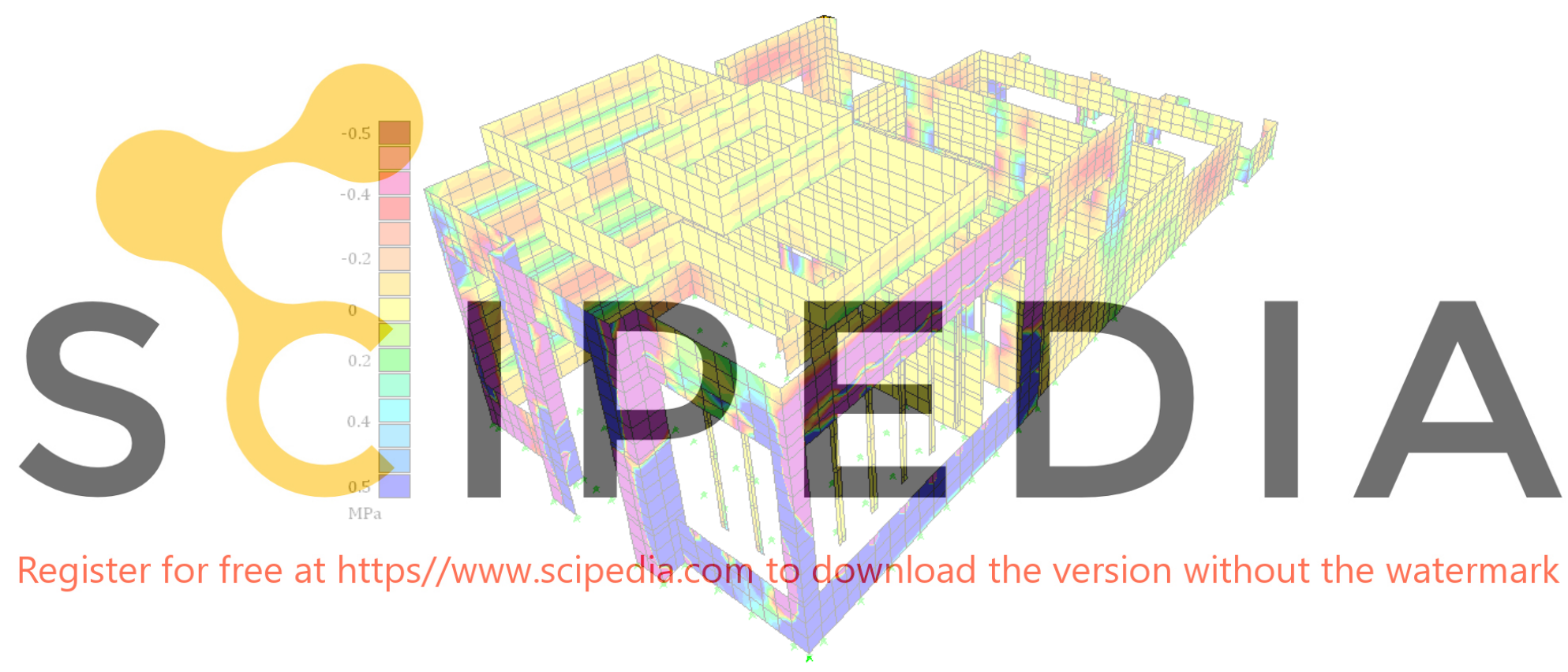

Figure 3: ETABS model of existing building

A lot of time was spent confirming that the model output was verifiable based on stresses on the building materials noted during on site assessments. The model is only as good as the level of accuracy is contains with the on-site existing conditions. For example, the existing building on site review of the masonry showed stress cracking and fractures at the North West corner of the MEB. When the model was reviewed, it also showed high levels of deflection and torsion at this same corner.

The on-site assessments also showed that there was masonry cracking at the corners of both the GWR Block and the Concourse Block, where the masonry walls had multi-storey unbraced heights. When reviewing the model, these corners were all high stress areas, due to excessive deflections and weak connections to the roof diaphragm. 
The model was responding the same way the existing building had over its lifetime. This is a critical requirement of a model on any rehabilitation project, the importance of which cannot be stressed enough. Once the model is in tune with the existing building's behavior, the model becomes an extremely useful tool for seismic upgrades that meet the intent of current codes without over strengthening or stiffening the building. There is a definite point, where stronger and stiffer solutions do not provide favourable results, as it changes the way the building has generally performed over the course of its lifetime, producing an overall negative effect.

\section{SEISMIC UPGRADES}

\subsection{Main Entrance Block (MEB)}

Seismic upgrades that were complete within the MEB were as follows:

- New concrete shearwalls were introduced around existing and new stairwells. The shearwalls introduced on the west side of the block were critical to minimizing the torsional seismic effects that the original building had, as the North and west elevations of this block had a lot of curtain walls above $2^{\text {nd }}$ floor level, with essentially no shear walls.

- All floor slabs were mechanically connected to masonry shear walls using Cintec
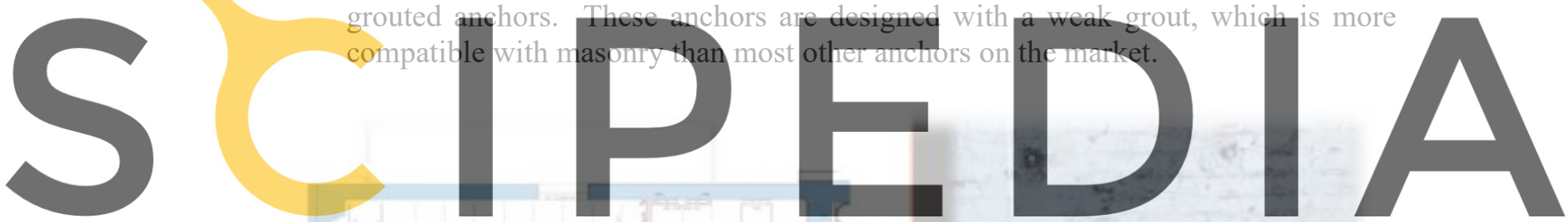

Register for free at https//www.scipedia.com to download the version without the watermark
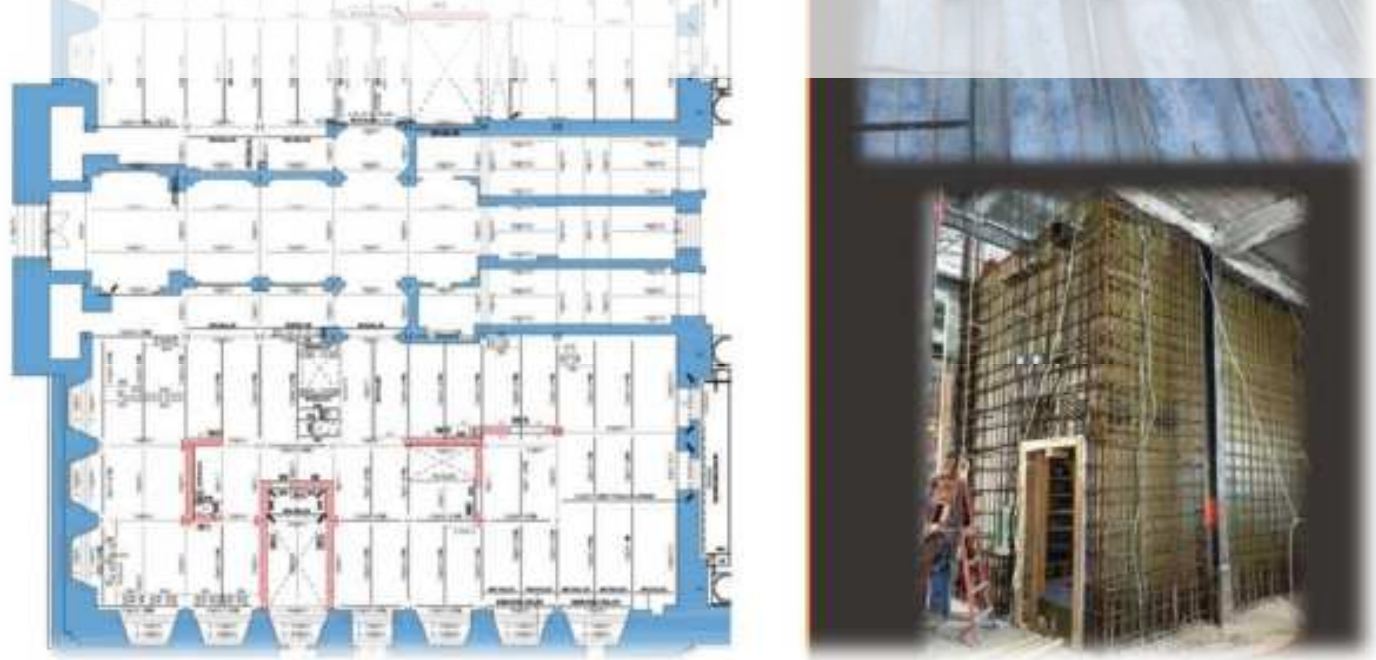

Figure 4: MEB Seismic Upgrades 


\subsection{General Waiting Room (GWR)}

Within this space, new $1^{\text {st }}$ floor level floor plates were constructed as stand alone structures. These were constructed from structural steel with $\mathrm{x}$-bracing and inset from the heritage perimeter walls so that new structure could be completely removed from the building without damage to the heritage finishes. Expansion joints surround the three sides of these new floor plates.

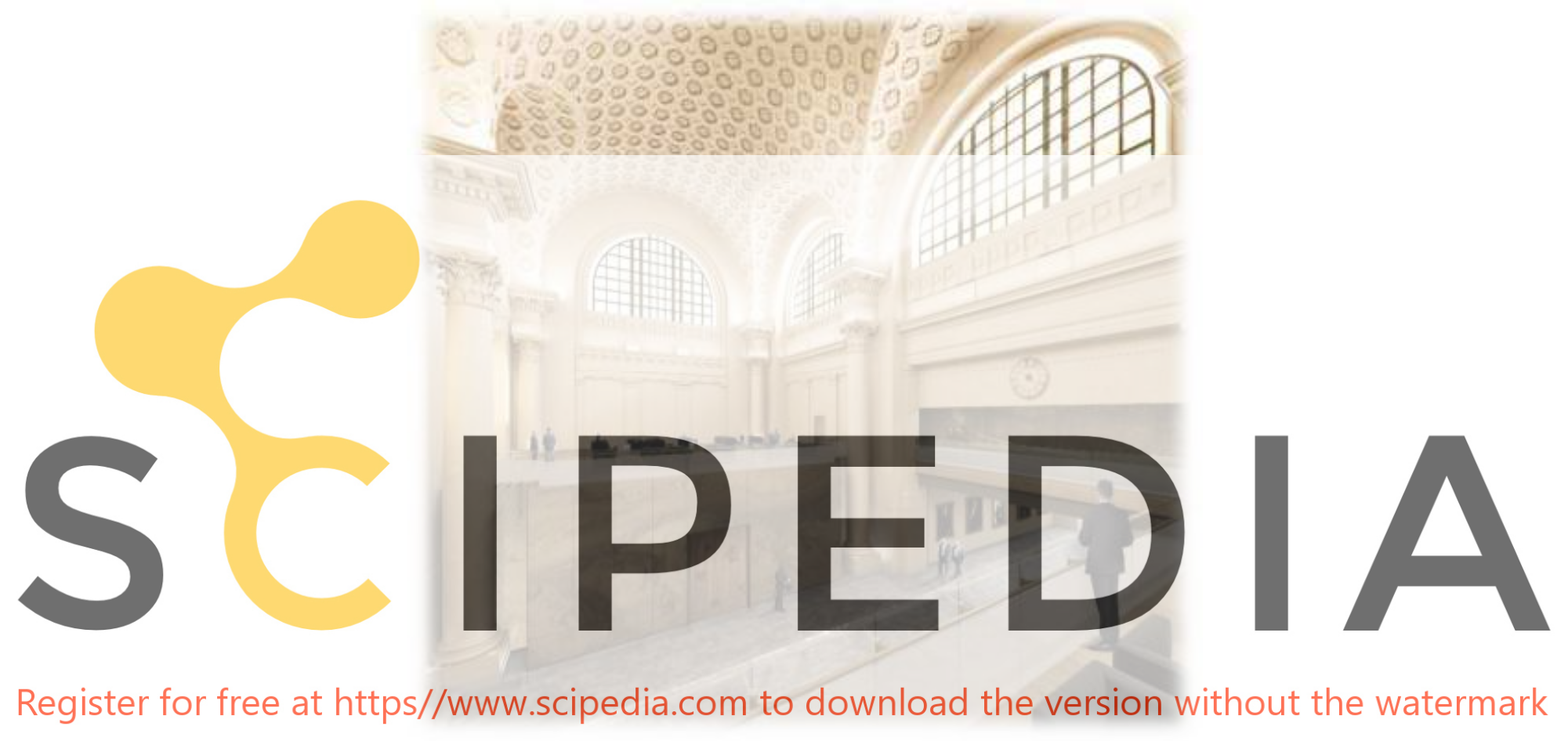

Figure 5: GWR looking east from the new western $1^{\text {st }}$ floor level

Within the attic space, steel x-bracing was introduced between the existing steel roof trusses, just under the plane of the existing timber roof diaphragm. This increased the strength of the roof, to decrease the torsional seismic effects the original building had which were causing the masonry to fracture at the corners of the building. The roof diaphragm was anchored to the top of these 4 storey walls, which also reduced deflection because the tops of these walls were no long unbraced.

\subsection{Ticketing Block}

As the best solution to making the functional program work within the existing building footprint, it was decided that the existing steel and concrete slab structure of the Ticketing Block would be demolished, and the exterior stone masonry facades would be shored to keep them intact. A new structure would then be built within the existing four perimeter masonry walls 
of this block. Structurally, this worked well, as new concrete shear walls could be positioned around new stairwells within the corners of this block, which would lend lateral support to the 4 storey masonry walls of the GWR at the north end of this block as well as the 2 storey free standing walls of the Concourse at the south end of this block.
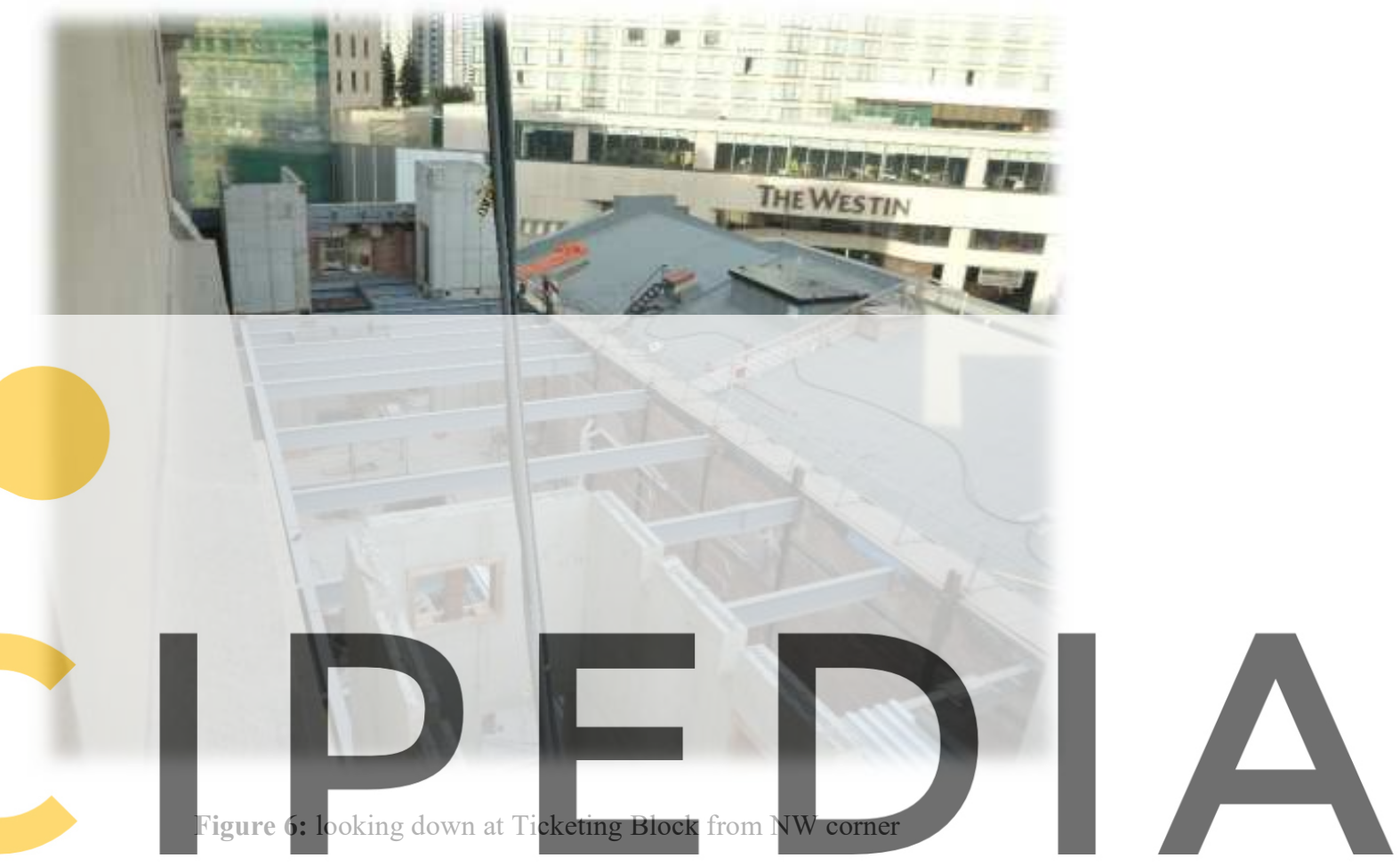

\section{Register for frecatubtips//www.scipedia.com to download the version without the watermark}

This block is the location of the house of the Senate of Canada, which meant that in addition to seismic concerns, a new $1^{\text {st }}$ floor level was required to allow for a balcony seating area around the perimeter of the chamber. This floor level was designed for the minimum number of penetrations through the high heritage fabric of the perimeter walls.

Additional to this scope, the roof of the Concourse was reinforced with steel x-bracing, very similar to the GWR roof noted in section 6.2 


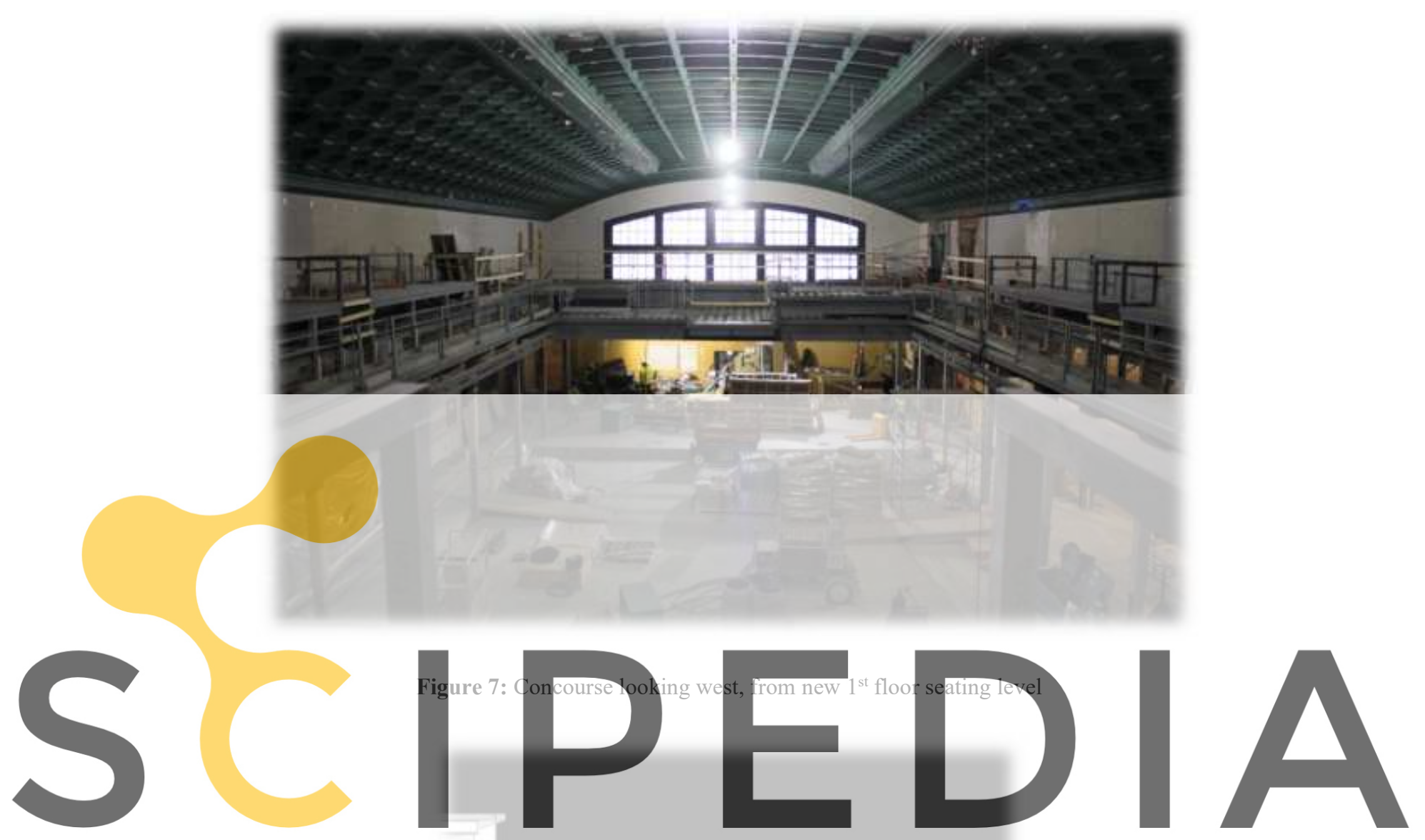

Register for free at https//www.scipedia.com to download the version without the watermark

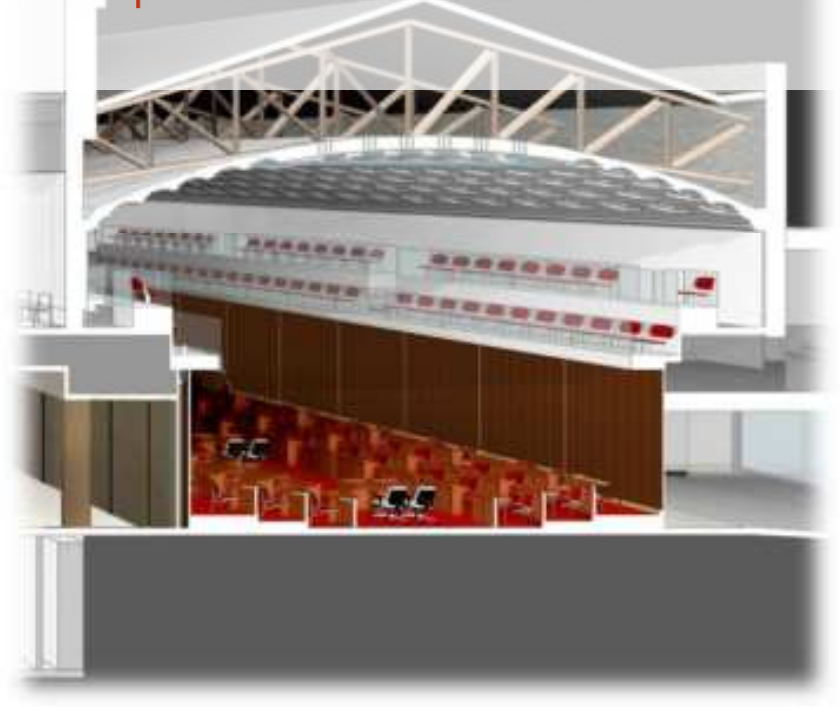

Figure 8: Perspective of new Concourse looking east 


\subsection{South Addition}

The seismic upgrade in this area of the building consisted of adding additional reinforcing into the cells of the concrete block masonry perimeter walls and grouting the reinforced cells, to strength critical areas. The existing concrete block masonry was originally unreinforced.

\section{CONCLUSIONS}

The conservation and rehabilitation of this building is a fantastic example of how much character and history a heritage building can provide a city and country's narrative. It is truly a service to the downtown core to save these heritage buildings and repurpose them for current needs. Sustainable design strategies were achieved throughout the project.

The repurposing of this existing heritage building adds to the richness of the streetscape and history of the City of Ottawa. Now that the public can access the building again, the structure is a part of the community in a way that it hadn't been in 55years.

The story of this building continues to unfold for decades and centuries to come.

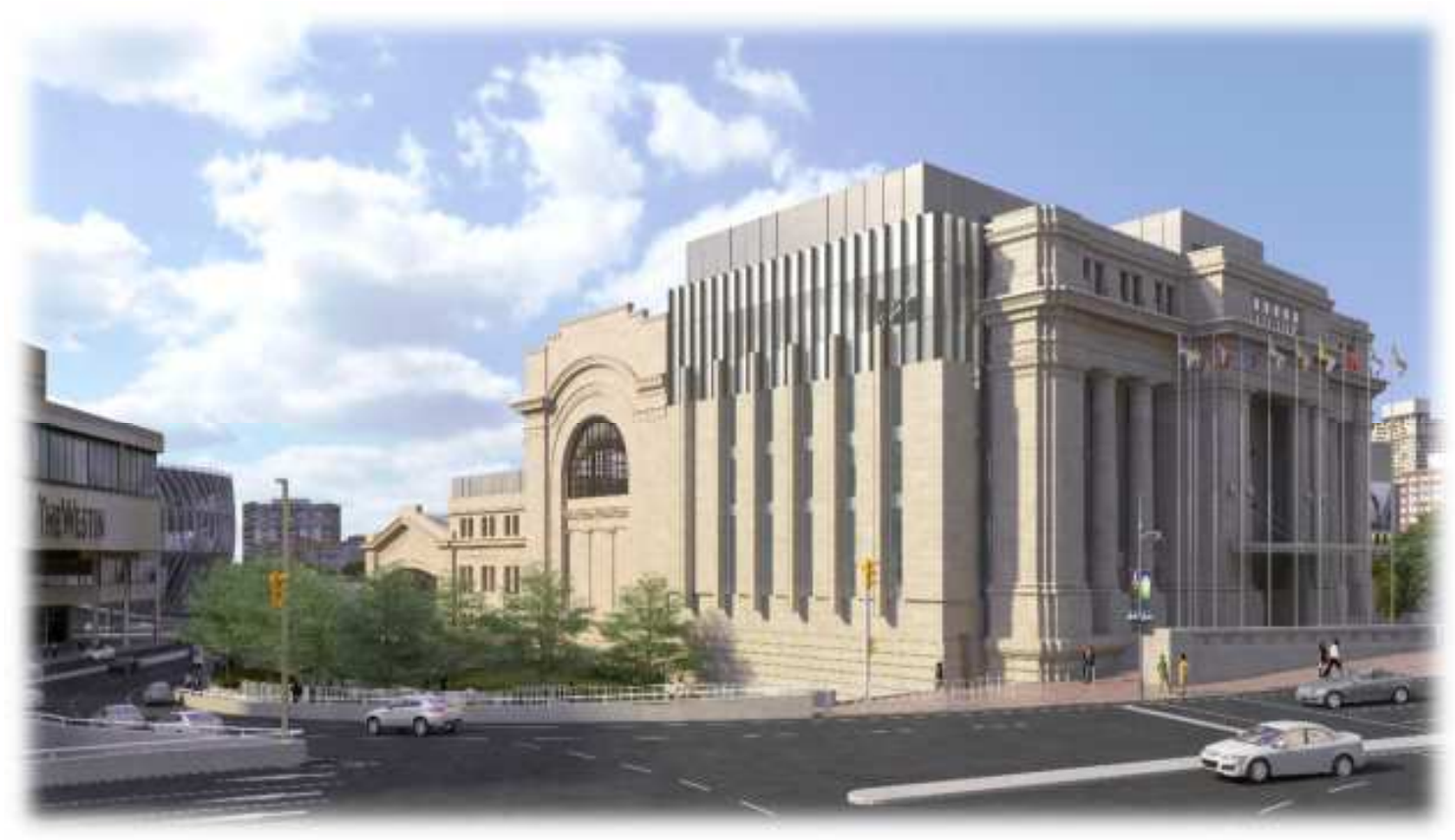

Figure 9: Exterior North East side of the Senate Building of Canada 
Acknowledgements. Integral in making this project a reality was the engineering team at John G. Cooke \& Associates Ltd., the Consultant team lead by Diamond Schmitt \& KWC Architects in Joint Venture, and PCL Construction who were the Construction Managers on the project. And of course, the Government of Canada for initiating the project and seeing it through. 